\title{
First Report on Pseudomonas marginalis Bacterium Causing Soft Rot of Onion in Morocco
}

\author{
Achbani E. H. ${ }^{*}$, S. Sadik ${ }^{1,2}$, R. El Kahkahi ${ }^{3}$, A. Benbouazza ${ }^{1}$, and H. Mazouz ${ }^{2}$ \\ ${ }^{1}$ Laboratory of Plant Protection URPP- INRA-Meknes Morocco; ${ }^{2}$ Laboratory of Plant Biotechnology and Mo- \\ lecular Biology, Faculty of Sciences, Meknes, Morocco; ${ }^{3}$ Faculty of Sciences, Kenitra, Morocco.
}

Received: November 18, 2013 / Accepted: October 31, 2014

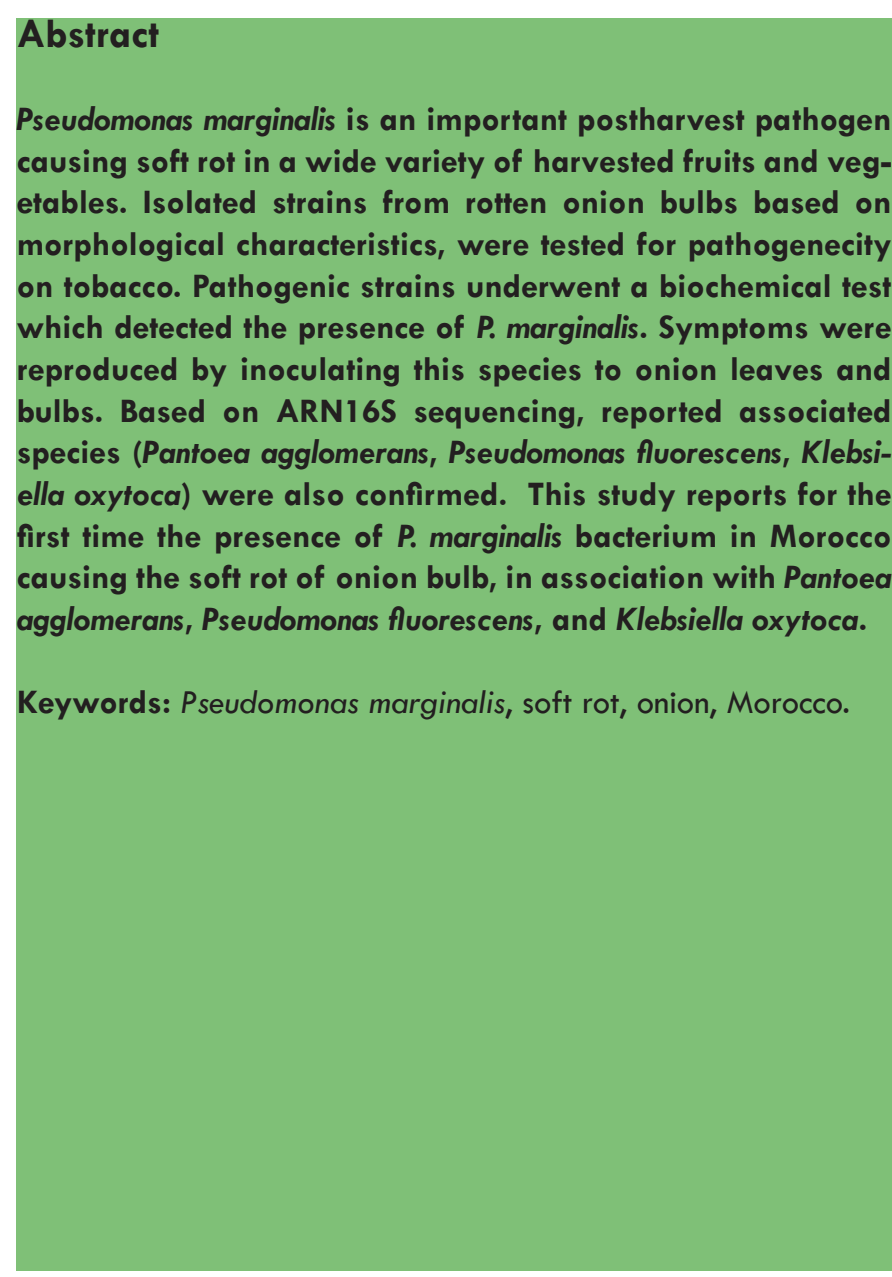

* Corresponding author: achbani105@gmail.com

\section{Introduction}

In Morocco, the onion crop (Allium cepa L.) has a high economical importance, representing $11 \%$ of nationally produced vegetable crops (Anonyme, 2011 ). However this crop is exposed to many physiological and phytosanitary constraints (Conn et al., 2012), among which, the onion bulb soft rot represents the most serious post harvest disease.

For onion storage two methods used in France, storage in a traditional dryer and temporary storage under plastic tunnels, also storage methods affect the soft rot incidence (Gourc et al., 2007).

The Pseudomonas and Pectobacterium bacterial genus are considered as the main bacteria that caused the damages in USA during storage (Agrios, 2005).

By means of pectinolytic enzyme products (pectin lyase and pectate lyase) (Hayashi et al., 1997, Liao et al., 1997), P. marginalis causes the post-harvest soft rot (Conn et al., 2012; Scortichini, 1994) of many harvested crops including: onion (Kim et al., 2002 ; Wright et al 1992 ; Dallaire, 2009), tomato (lbe and Grogan, 1983), salad (Blancard et al., 2003), potato (Elumalai and Mahadevan, 1995), broccoli (Charron et al., 2002) and carrot (Godfrey and Marshall., 2002). P. marginalis is a foliar as well as a post-harvest disease (Conn et al., 2012; Scortichini, 1994). It's a bacterium present in Europe, India, South American, USA, Japan, New Zealand and Austria, etc.

Development of the soft rot disease caused by $P$. marginalis is optimal at low temperatures (between 5 and $25^{\circ} \mathrm{C}$ ), the bacteria develop at $0^{\circ} \mathrm{C}$ and it can induce the soft rot at $5^{\circ} \mathrm{C}$ on onion crop (Kim et al., 2002). In Morocco, no evidence of such bacteria causing soft rot on onion or another crop.

The main objective of this work was to isolate and identify the
ATLOS Publishing, LP
This is an Open Access article distributed under the terms of the Creative Commons Attribution License (http://creativecommons.org/licenses/by/3.0/), which permits unrestricted use, distribution, and reproduction in any medium, provided the original work is properly cited. 
causal agent of the bacterial soft rot on onion bulbs in Morocco using biochemical, molecular and pathogenicity tests.

\section{Materials and Methods}

\section{Isolation}

Onion bulbs showing soft rot symptoms (Fig. 1) were sampled in March 2012 from vegetables storage areas at Elhaijeb (N $33^{\circ} 41.45, \mathrm{~W} 5^{\circ} 22$ 00) (Meknes-Tafilalt, Morocco).

Onion bulbs showing water-soaking or yellowish-brown rot were used for isolation. These were washed with tap water and cut longitudinally. The diseased scale tissues were cut into $5 \mathrm{~mm}$ cubes by using sterilized surgical blade. Three pieces of onion scale were ground in $1 \mathrm{ml}$ of distilled water using a mortar and pestle. The suspension was streaked onto LPGA (yeast extract, 5g; peptone, 5g; glucose, 10g; agar, 18g; and distilled water, $1 \mathrm{I}$ ) and King B (proteose peptone, $20 \mathrm{~g} ; \mathrm{K}_{2} \mathrm{HPO}_{4} \cdot 3 \mathrm{H}_{2} \mathrm{O}, 2.5$ $\mathrm{g} ; \mathrm{MgSO}_{4} \cdot 7 \mathrm{H}_{2} \mathrm{O}, 6 \mathrm{~g}$; glycerol, $15 \mathrm{ml}$; agar, $15 \mathrm{~g}$; and distilled water, 1 I) mediums. Six bacterial isolates were identified by biochemical and physiological tests including Gram strain; LOPAT (Levan production, Oxidase reaction, Potato soft rot, Arginine dishydrolase $[\mathrm{ADH}]$ and Tobacco hypersensitivity) test, Hydrolysis of Tween80, mobility test, Indole, Mannitol, Catalase, Hugh \& Leifson (H.L), the bacteria development in low and high temperature $\left(4\right.$ and $40^{\circ} \mathrm{C}$ ), the salt tolerance $(7$ and $10 \%$ of $\mathrm{NaCl}$ ) and API 20 gallery. All tests were repeated at last twice (Schaad et al., 2001).

\section{Pathogenicity Test}

Cultures of bacterial isolates obtained from onion bulbs, labeled 2078-6-1, 2078-6-2, 2078-6-3, 2078-6-4, 2078-6-5, were used in a greenhouse pathogenicity experiment. In vivo, seven weeks old tomato plants grown in greenhouse and sixteen weeks old onion plants grow in nursery were inoculated. A suspension of tested bacterial isolate $\left(1 \times 10^{8} \mathrm{CFU} / \mathrm{ml}\right)$ in sterile distilled water from 24-h cultures was used as the inoculums; plants in one experimental variant were inoculated by injection of approximately $0.2 \mathrm{ml}$ of inoculums into leaves of onion and

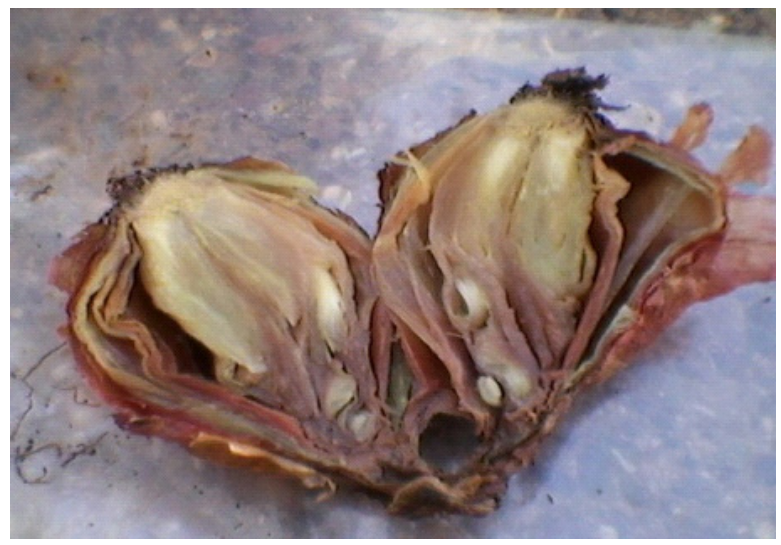

Figure 1. Onion soft rot. tomato plants. The plants were incubated in a greenhouse at $20^{\circ} \mathrm{C}$ to $25^{\circ} \mathrm{C}$ and $60-70 \%$ relative humidity. Sterile water was used as control (Kudela et al., 2010). In vitro, onion bulbs and leaves, and tomato leaves were inoculated by a suspension $\left(10^{8}\right.$ $\mathrm{CFU} / \mathrm{ml}$ ) of 24-h bacterial culture; the vegetable material was incubated in moist chamber at a temperature of $30^{\circ} \mathrm{C}$, after five days of incubation symptoms were observed.

\section{PCR Amplification}

To complete the biochemical results, a molecular identification by sequencing was performed. The extraction was made using GenElute Mammalian Genomic Kit (Anonyme, 2010). Quantification of DNA was performed using spectrophotometry. Amplification was performed with primers Fdl (CAGAGTTTGATCCTGGCTCAG) and RP2 (AGAGTTTGATCCTGGCTCAG) at a PCR kit (Invitrogen). The PCR was carried out in a total volume of $25 \mu \mathrm{l}$ of the following reaction mixture: $2.5 \mu \mathrm{l} 10 \mathrm{X}$ Buffer, $2 \mu \mathrm{l}$ dNTP $(10 \mathrm{~mm}), 0.125 \mu \mathrm{l}$ of each primer $(100 \mu \mathrm{M}), 0.75 \mu \mathrm{MgCl}_{2}$ $(50 \mathrm{mM}), 0.2 \mu \mathrm{l} \mathrm{Taq}(5 \mathrm{U} / \mu \mathrm{l})$ and $5 \mu \mathrm{l}$ DNA. The PCR was performed using the following protocol: initial denaturation at $96^{\circ} \mathrm{C}$ for $4 \mathrm{~min}$, followed by 35 cycles of denaturation at $96^{\circ} \mathrm{C}$ for $0.1 \mathrm{~min}$, annealing at $52^{\circ} \mathrm{C}$ for $0.4 \mathrm{~min}$, and a extension at $72^{\circ} \mathrm{C}$ for $2 \mathrm{~min}$, followed by an additional extension at $72^{\circ} \mathrm{C}$ for $4 \mathrm{~min}$. Electrophoresis was performed in $1.5 \%$ agarose gel. Purification of PCR products was carried using the enzyme EXO-SAT according to the following schedule: $37^{\circ} \mathrm{C}$ for $15 \mathrm{~min}$ following by $80^{\circ} \mathrm{C}$ for $15 \mathrm{~min}$.

\section{S DNA Sequencing and Sequence Analysis}

Selected PCR fragments, amplified from the isolates tested for pathogenicity, were sequenced in both strands, with the $\mathrm{pA}$ and $\mathrm{pH}^{\prime}$ primers, using the BigDye terminator cycle sequencing ready reaction FS kit. So the sequencing of amplification product was carried out in a total volume of $10 \mu \mathrm{l}$ of the following reaction mixture: $1 \mu \mathrm{l}$ BigDye, $3 \mu \mathrm{l}$ sequencing buffer $x 5, x \mu l$ primer (3.2-5pmol), (0.75-1.5) $\mu$ l DNA matrice, (2.5-3.25) $\mu \mathrm{l}$ $\mathrm{H}_{2} \mathrm{O}$ (MiliQ). The sequencing was performed using the following protocol: initial denaturation at $96^{\circ} \mathrm{C}$ for $1 \mathrm{~min}$, followed by 25 cycles of denaturation at $96^{\circ} \mathrm{C}$ for $10 \mathrm{~s}$, annealing at $50^{\circ} \mathrm{C}$ for $5 \mathrm{~s}$, and a extension at $60^{\circ} \mathrm{C}$ for $4 \mathrm{~min}$, followed by an additional extension at $72^{\circ} \mathrm{C}$ for $4 \mathrm{~min}$.

Reading of sequencing results was done using NCBI-BLAST software (Altschul et al., 1997).

\section{Results and Discussion}

Bacterial colonies which were consistently isolated from infected samples were fluorescent on King's medium B. All six (2078-6-1, 2078-6-2, 2078-6-3, 2078-6-4, 2078-6-5 and 2078-6-6) strains caused hypersensitive reaction (HR) on tobacco leaves, indicating that they were pathogenic. They were Gram-negative. According to the LOPAT tests, the isolates were negative for Levan production and positive for Oxidase test, Pectinase test (Fig. 2) and Arginine dihydrolase. Based on the LOPAT and Gram tests (Schaad et al., 2001) and Kim et al. 
(2002) results, representative isolates of the causal agent of soft rot of onion bulbs in Morocco was identified as $P$. marginalis, they also showed that strains can grow in a concentration of 7 and $10 \%$ of salt at $24^{\circ} \mathrm{C}$ with $\mathrm{pH} 7$. These results were different from those of Membre and Burlot (1994) who showed that, a lesser concentration of $2.5 \%$ of $\mathrm{NaCl}$ reduced $P$. marginalis growth and inhibited pectinolytic enzyme production. The conflicting results may be due to strains natures and isolation origins. All of our strains were Catalase positive and capable of hydrolyzing Esculin, but not Tween 80 and Gelatin. None of the strains were able to produce Indole and reduce nitrate. However, all strains showed ability to utilize Arginine, Lysine (LDC), Ortnithine

Table 1. P. marginalis strains (2078-6-1, 2078-6-2, 2078-6-3, 2078-6-4, 2078-6-5,) behavior on gallery API20, classic biochemical tests and growth at different temperatures. (ONPG : determination of enzyme beta-galactosidase presence, ADH : transformation of arginine by dishydrolase argnine, LDC : transformation of lysine by decarboxylase lysine, ODC : transformation of ornithine by decarboxylase ornithine, CIT : utilization of citrate as alone source of Carbone, $\mathrm{H} 2 \mathrm{~S}$ : production of hydrogen sulfate from thiosulfate, URE : liberation of ammoniac from urea by urease, TDA : formation of indolepyruvique acid from tryptophan by desaminase tryptophan, IND : formation of indole from tryptophan, VP : formation of acetone from sodium piruvate, GEL : liquefaction of gelatin, GIU : Glucose, MAN : Mannitol, INO : Inositol, SOR : Sorbitol, , RHA : Rhamnose, SAC : Sucrose, MEL : Melibiose, AMY : Amygdaline, ARA : Arabinose (formation of acid by utilization of carbon hydrate tests ) ((-): Negative; (+): Positive; ND: No determinate).

\begin{tabular}{|c|c|c|c|c|c|c|}
\hline Strains & 2078-6-1 & $2078-6-2$ & $2078-6-3$ & $2078-6-4$ & 2078-6-5 & $2078-6-6$ \\
\hline Levan & $(+)$ & $(+)$ & $(+)$ & $(+)$ & $(+)$ & $(+)$ \\
\hline Oxidase & $(+)$ & $(+)$ & $(+)$ & $(+)$ & $(+)$ & $(+)$ \\
\hline Pectinase & $(+)$ & $(+)$ & $(+)$ & $(+)$ & $(+)$ & $(+)$ \\
\hline ADH & $(+)$ & $(+)$ & $(+)$ & $(+)$ & $(+)$ & $(+)$ \\
\hline H. Tabac & $(+)$ & $(+)$ & $(+)$ & $(+)$ & $(+)$ & $(+)$ \\
\hline Growth at $41^{\circ} \mathrm{C}$ & $(+)$ & $(+)$ & $(+)$ & $(+)$ & $(+)$ & $(+)$ \\
\hline Growth at $4^{\circ} \mathrm{C}$ & $(+)$ & $(+)$ & $(+)$ & $(+)$ & $(+)$ & $(+)$ \\
\hline H.L & $(-)$ & $(-)$ & $(-)$ & $(-)$ & $(-)$ & $(-)$ \\
\hline Catalase & $(+)$ & $(+)$ & $(+)$ & $(+)$ & $(+)$ & $(+)$ \\
\hline Hydrolysis of Tween 80 & $(-)$ & $(-)$ & $(-)$ & $(-)$ & $(-)$ & $(-)$ \\
\hline Mobility & $(+)$ & $(+)$ & $(+)$ & $(+)$ & $(+)$ & $(+)$ \\
\hline Esculine & $(+)$ & $(+)$ & $(+)$ & $(+)$ & $(+)$ & $(+)$ \\
\hline ONPG & $(+)$ & $(+)$ & $(+)$ & $(+)$ & $(+)$ & $(+)$ \\
\hline LDC & $(+)$ & $(+)$ & $(+)$ & $(+)$ & $(+)$ & $(+)$ \\
\hline ODC & $(+)$ & $(+)$ & $(+)$ & $(+)$ & $(+)$ & $(+)$ \\
\hline CIT & $(-)$ & $(-)$ & $(-)$ & $(-)$ & $(-)$ & $(-)$ \\
\hline $\mathrm{H} 2 \mathrm{~S}$ & $(+)$ & $(+)$ & $(+)$ & $(+)$ & $(+)$ & $(+)$ \\
\hline URE & $(+)$ & $(+)$ & $(+)$ & $(+)$ & $(+)$ & $(+)$ \\
\hline TDA & ND & ND & ND & ND & ND & ND \\
\hline IND & $(-)$ & $(-)$ & $(-)$ & $(-)$ & $(-)$ & $(-)$ \\
\hline VP & $(-)$ & $(-)$ & $(-)$ & $(-)$ & $(-)$ & $(-)$ \\
\hline GEL & $(-)$ & $(-)$ & $(-)$ & $(-)$ & $(-)$ & $(-)$ \\
\hline GLU & $(+)$ & $(+)$ & $(+)$ & $(+)$ & $(+)$ & $(+)$ \\
\hline MAN & $(+)$ & $(+)$ & $(+)$ & $(+)$ & $(+)$ & $(+)$ \\
\hline INO & $(-)$ & $(-)$ & $(-)$ & $(-)$ & $(-)$ & $(-)$ \\
\hline SOR & $(+)$ & $(+)$ & $(+)$ & $(+)$ & $(+)$ & $(+)$ \\
\hline RHA & $(+)$ & $(+)$ & $(+)$ & $(+)$ & $(+)$ & $(+)$ \\
\hline SAC & $(+)$ & $(+)$ & $(+)$ & $(+)$ & $(+)$ & $(+)$ \\
\hline MEL & $(+)$ & $(+)$ & $(+)$ & $(+)$ & $(+)$ & $(+)$ \\
\hline AMY & $(+)$ & $(+)$ & $(+)$ & $(+)$ & $(+)$ & $(+)$ \\
\hline ARA & $(+)$ & $(+)$ & $(+)$ & $(+)$ & $(+)$ & $(+)$ \\
\hline NO2 & $(-)$ & $(-)$ & $(-)$ & $(-)$ & $(-)$ & $(-)$ \\
\hline N2 & $(-)$ & $(-)$ & $(-)$ & $(-)$ & $(-)$ & $(-)$ \\
\hline
\end{tabular}

(-): Negative; (+): Positive; ND: Indeterminate 
Table 2. Table 2. The sequence identity/similarity. (The sequences of the isolates strain amplified by RNA $16 \mathrm{~S}$, present a $99 \%$ similarity with the LMG 2214 Pseudomonas marginalis several strain (1204b/1208b with a score equal to 2165 bits (2400)).

\begin{tabular}{|c|c|c|c|c|c|}
\hline $\begin{array}{l}\text { The Sequence of Isolates strains (2078-6-1, } \\
2078-6-2,2078-6-3,2078-6-4,2078-6-5 \text {, } \\
2078-6-6 \text { ) }\end{array}$ & Sequence & elden & itity/Similarity & & $\begin{array}{l}\text { GenBank Accession } \\
\text { Numbers }\end{array}$ \\
\hline GCCTAGGAATCTGCCTGGTAGTGGGGGA & & & & & HE586394.1 \\
\hline TAACGTCCGGAAACGGACGCTAATACCGC & sojer & :9 & IIIIIIIIIIIIIIIIIIIIIIIIIIIII IIIIIIIIIIIIIIIIIIIIIIII & 248 & \\
\hline ATACGTCCTACGGGAGAAAGCAGGGGAC & guery & 61 & 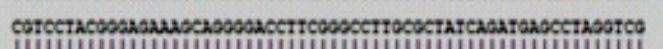 & 120 & \\
\hline CTTCGGGCCTGCGCTATCAGATGAGCCTA & sojes & 149 & 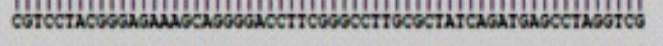 & 200 & \\
\hline GGTCGGATTAGCTAGTTGGTGGGGTAATG & Query & 122 & 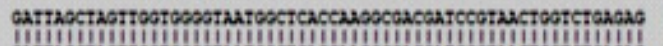 & 180 & \\
\hline GCTCACCAAGGCGACGATCCGTAACTGGT & sojer & 209 & 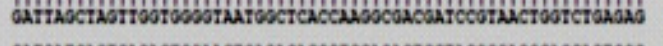 & 268 & \\
\hline CTGAGAGGATGATCAGTCACACTGGAACT & Query & 218 & 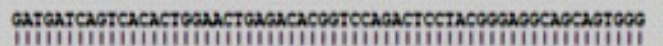 & 240 & \\
\hline GAGACACGGTCCAGACTCCTACGGGAGG & sojet & & 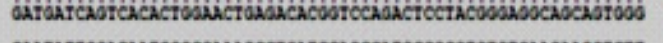 & 328 & \\
\hline CAGCAGTGGGGAATATTGGACAATGGGC & goery & & 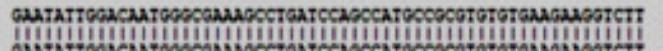 & 300 & \\
\hline GAAAGCCTGATCCAGCCATGCCGCGTGTG & soerty & 320 & 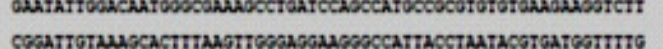 & 360 & \\
\hline TGAAGAAGGTCTTCGGATTGTAAAGCACTT & soyet & $3: 9$ & 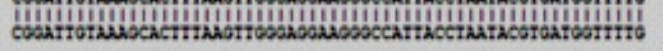 & 46 & \\
\hline TAAGTTGGGAGGAAGGGCCATTACCTAAT & Qvery & 36: & 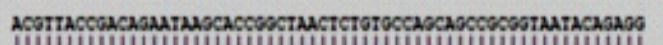 & 420 & \\
\hline ACGTGATGGTTTIGACGTTACCGACAGAAT & soget & 449 & 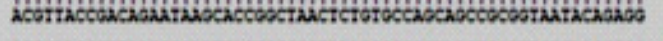 & sot & \\
\hline AAGCACCGGCTAACTCTGTGCCAGCAGCC & guery & 421 & 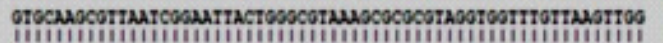 & 480 & \\
\hline GCGGTAATACAGAGGGTGCAAGCGTTAAT & soget & 909 & 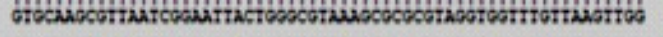 & $36 t$ & \\
\hline CGGAATACTGGGCGTAAAGCGCGCGTA & Query & & 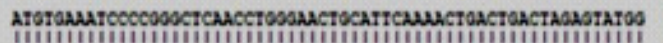 & 540 & \\
\hline GGTGGTTTGTTAAGTTGGATGTGAAATCCC & sobet & & 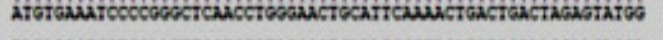 & 620 & \\
\hline CGGGCTCAACCTGGGAACTGCATTCAAAA & Suety & & 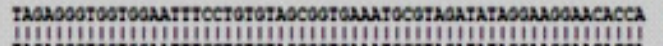 & 600 & \\
\hline CTGACTGACTAGAGTATGGTAGAGGGTG & 30) & & 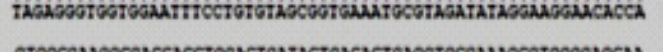 & 600 & \\
\hline GTGGAATTCCTGTGTAGCGGTGAAATGC & seger & & 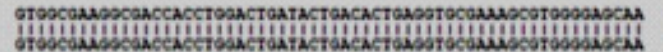 & 660 & \\
\hline GTAGATATAGGAAGGAACACCAGTGGCG & suery & & G & 700 & \\
\hline & seget & 74 & 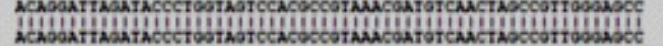 & 720 & \\
\hline AAGGCGACCACCTGGACTGATACTGACAC & suery & ?2: & 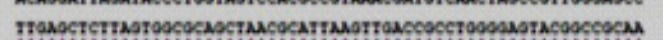 & not & \\
\hline TGAGGTGCGAAAGCGTGGGGAGCAAAC & seget & sos & 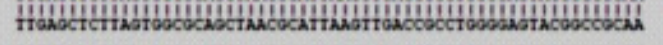 & set & \\
\hline AGGATTAGATACCCTGGTAGTCCACGCCG & Guery & 901 & if7. & 146 & \\
\hline TAAACGATGTCAACTAGCCGTTGGGAGCC & & & 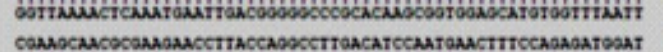 & $n$ & \\
\hline TTGAGCTCTAGTGGCGCAGCTAACGCATT & seset & s? & 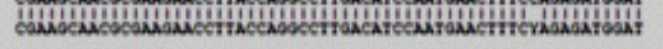 & $m$ & \\
\hline AAGTTGACCGCCTGGGGAGTACGGCCGC & suery & 201 & 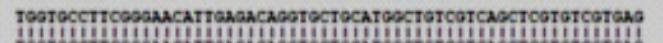 & wo & \\
\hline AAGGTTAAAACTCAAATGAATTGACGGGG & seget & s" & 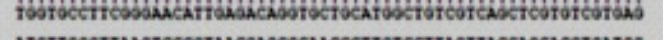 & 1040 & \\
\hline GCCCGCACAAGCGGTGGAGCATGTGGI & $\begin{array}{l}\text { Suery } \\
\text { sejet }\end{array}$ & $\begin{array}{l}n+1 \\
1040\end{array}$ & 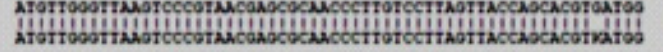 & $\begin{array}{l}1020 \\
1100\end{array}$ & \\
\hline TAATTCGAAGCAACGCGAAGAACCTACCA & every & 2021 & 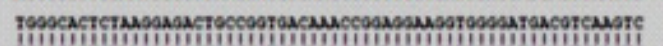 & 1000 & \\
\hline GGCCTTGACATCCAATGAACTTTCCAGAGA & sejet & 1100 & 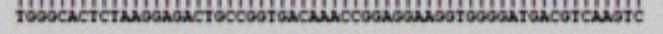 & $116 t$ & \\
\hline 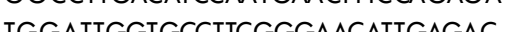 & owery & 1001 & 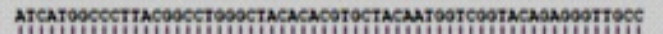 & 1140 & \\
\hline TGGATTGGTGCCTTCGGGAACATTGAGAC & stejet & 1168 & 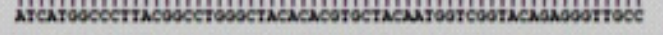 & 1220 & \\
\hline AGGTGCTGCATGGCTGTCGTCAGCTCGTG & suery & 1141 & 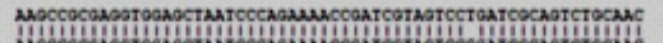 & 1200 & \\
\hline TCGTGAGATGTTGGGTTAAGTCCCGTAAC & $\begin{array}{l}\text { seject } \\
\text { suery }\end{array}$ & $\begin{array}{l}1220 \\
1201\end{array}$ & 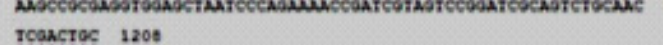 & 1211 & \\
\hline GAGCGCAACCCTTGTCCTAGTACCAGCA & seget & 120" & tosactoc 1296 & & \\
\hline CGTGATGGTGGGCACTCTAAGGAGACTG & & & & & \\
\hline CCGGTGACAAACCGGAGGAAGGTGGGG & & & & & \\
\hline ATGACGTCAAGTCATCATGGCCCTACGGC & & & & & \\
\hline CTGGGCTACACACGTGCTACAATGGTCGG & & & & & \\
\hline TACAGAGGGTTGCCAAGCCGCGAGGTG & & & & & \\
\hline GAGCTAATCCCAGAAAACCGATCGTAGTC & & & & & \\
\hline CTGATCGCAGTCTGCAACTCGACTGC & & & & & \\
\hline
\end{tabular}




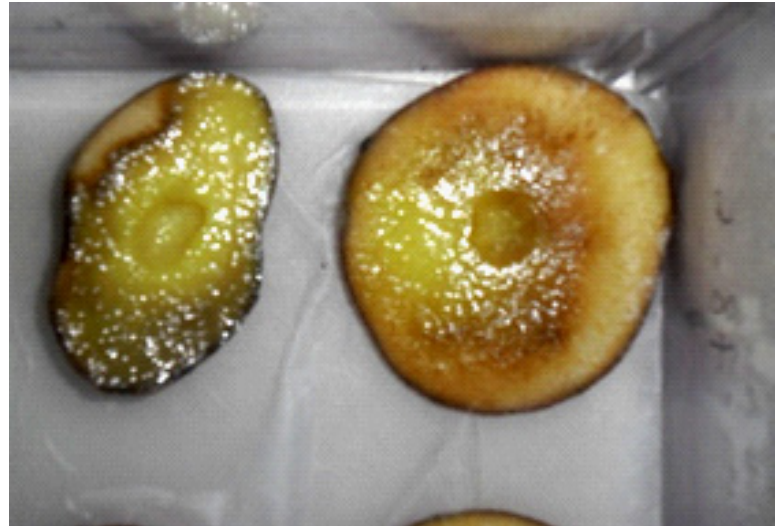

Figure 2. Pectinase test. Symptoms induced by artificial inoculation of isolates of $P$. marginalis.

(ODC), Thiosulfate (H2S), Urea (URE), Glucose (GLU), Mannitol (MAN), Sorbitol (SOR), Rhamnose (RHA), Sucrose (SAC), Melibiose (MEL), Amygdaline (AMY), Arabinose (ARA), but they did not use Citrate (CIT), Tryptophan (IND), Sodium Piruvate (VP), Gelatin (GEL), Inositol (INO) (Table 1).

The strains can grow at $4{ }^{\circ} \mathrm{C}$; low temperatures during this season (2011-2012) may have favored soft rot $P$. marginalis bacteria development. These results correlate with those of Kim et al. (2002), who showed that the optimal temperature development is $0^{\circ} \mathrm{C}$. Also we have shown the development strains at $40^{\circ} \mathrm{C}$.

\section{Pathogenicity Test}

The 2078-6-1, 2078-6-2, 2078-6-3, 2078-6-4, 2078-6-5 and 2078-6-6 strains gave a positive reaction in vitro (Fig. 3) and in planta. In vitro tests showed that there was development of soft rot after five days of incubation on onion bulbs by $P$. marginalis as indicated by chlorosis of infected area and necrosis development at onion and tomato leaves. In planta tests necrosis development was observed in onion and tomato leaves, after five days of incubation and after 14 days onion leaves died. Dallaire (2009) and (lbe and Grogan, 1983) show that $P$.

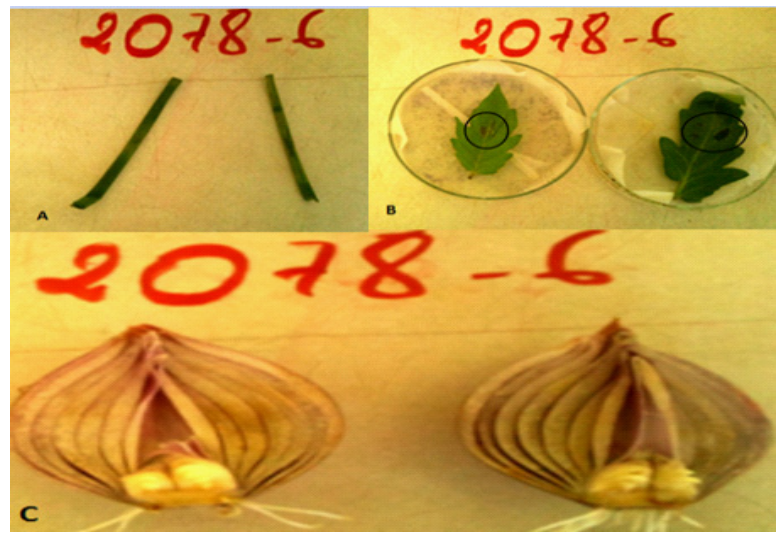

Figure 3. In vitro symptoms induced by artificial incubation. (a) Yellowing of onion leaves. (b) Necrosis in tomato leaves. (c) Soft rot in onion bulbs, after five days of inoculation. marginalis is a cause of onion and tomato decay.

\section{Molecular Results}

Result of DNA quantification showed that the quantity of DNA was sufficient for PCR (20.18 ng/ $\mu \mathrm{l})$. A band with $1550 \mathrm{bp}$ size was observed in agarose gel (Fig. 4). Analysis of the 16SrDNA sequence, by BLAST-NCBI, revealed that, the strains isolates (2078-6-1, 078-6-2, 2078-6-3, 2078-6-4, 2078-6-5and 2078-6-6) were identical (100\% identity over 1208 nucleotides) and that they were most closely related to $16 \mathrm{~S}$ rDNA sequences from several strains of $P$. marginalis (LMG 2214) (Table 2). We also found the presence of associated bacteria namely: Pantoea agglomerans, Pseudomonas fluorescens, and Klebsiella oxytoca. El-hendawy (2004) showed that Serratia marcescens and Klebsiella oxytoca are associated bacteria with P. marginalis in onion crop.

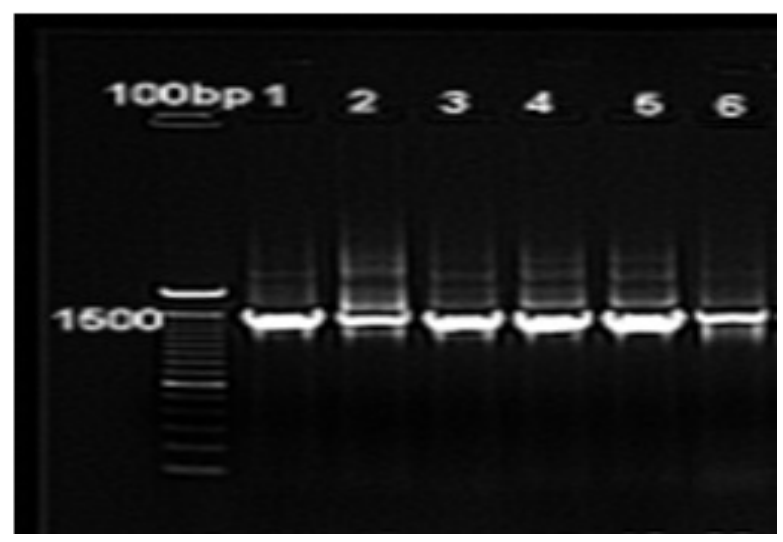

Figure 4. Electrophoritic profile of $P$. marginalis stains: (1) 2078-6-1. (2) 2078-6-2. (3) 2078-6-3. (4) 2078-6-4. (5) 2078-6-5. (6) 2078-6-6. (T+) P. marginalis reference strain. (T-) Negative control $\left(\mathrm{H}_{2} \mathrm{O}\right)$.

To our knowledge, this is the first report of bacterial bulbs soft rot of onion in Morocco. Because the soft rot of onion is the most danger disease during storage, this study is considered as a basic of others works that will target the $P$. marginalis ecologic and behaviors, to solve the soft rot problem by applying of a biological control. A development of a molecular method is very important for a rapid detection of $P$. marginalis in soft rot bulbs.

\section{References}

Agrios GN (2005) Plant pathology. Fifth edition, Elsevier academic press, 922p.

Altschul SF, Madden TL, Schaffer AA, Zhang J, Zhang Z, W Miller, and DJ Lipman (1997) Gapped BLAST and PSI-BLAST: a new generation of protein database search programs. Nucleic Acids Res (25): 3389-3402.

Anonyme (2010) GenElute ${ }^{T M}$ Mammalian Genomic DNA Miniprep Kit, User Guide, 16p.

Anonyme (2011) Ministère de l'agriculture et de la pêche maritime. Web site : http://www.marocagriculture.com.

Blancard D, H Lot, and B Maisonneuve (2003) Maladie des salades identifier, connaître et maîtriser, INRA, Paris, 277p. 
Charron CS, CE Samsm, and CH Canaday (2002) Impact of glucosinolate content in broccoli (Brassica oleracea) on growth of Pseudomonas marginalis, a causal agent of bacterial soft rot. Plant Dis (86): 629-632.

Conn EK, JS Lutton, and SA Rosenberger (2012) Onion Disease guide. Plant Health, 72p.

Dallaire C (2009) La pourriture molle de l'oignon : levures ou bactéries? Rien de mieux qu'un test de laboratoire! Fiche technique, Québuc, 4p.

El-Hendawy HH (2004) Association of pectolytic fluorescent pseudomonads with postharvest rots of onion. Phytopathol. Mediterr (43): 369-376.

Elumalai PP and A Mahadevan (1995) Characterization of pectate lyase produced by Pseudomonas marginalis and cloning of pectate lyase genes. Physiological and Molecular. Plant Pathology (46): 109-119.

Godfrey SAC and JW Marshall (2002) Identification of cold-tolerant Pseudomonas viridiflava and P. marginalis causing severe carrot postharvest bacterial soft rot during refrigerated export from $\mathrm{New}$ Zealand. Plant Pathology (51): 155-162.

Gourc D, D Monnier, and JD Payet (2007) Oignon guide pratique, lle de la réunion, France. Fiche technique ( $w w w$.armeflhor.fr).

Hayashi K, Y Inove, M Shiga, S Sato, R Tankano, K Hirayae, T Hibi, and $S$ Hara (1997) Pectinolytic enzymes from Pseudomonas marginalis. maff03-01173 45 (7): 1359-1363.

lbe SN and RG Grogan (1983) Effect of controlled oxygen and carbon dioxide atmospheres on bacterial growth rate and soft rot of tomato fruits caused by Pseudomonas marginalis. Plant disease (67): 1005-1008.

Kim YK , SD Lee, CS Choi, SB Lee, and SY Lee (2002) Soft Rot of Onion Bulbs Caused by Pseudomonas marginalis Under Low Temperature Storage. Plant Pathology J 18 (4): 199-203.

Kudela V, V Krejzar, and I Pankova (2010) Pseudomonas corrugata and Pseudomonas marginalis associated with the collapse of tomato plants in rockwool slab hydroponic culture. Plant Protect. Sci (46): $1-11$.

Liao C-H, DE McCallus, WF Fett, and YG Kang (1997) Identification of gene loci controlling pectate lyase production and soft-rot pathogenicity in Pseudomonas marginalis. Can. J. Microbiol (43): 425-431.

Membre JM and PM Burlot (1994) Effects of Temperature, $\mathrm{pH}$, and $\mathrm{NaCl}$ on Growth and Pectinolytic Activity of Pseudomonas marginalis. Applied and environmental microbiology 60 (6): 2017-2022.

Schaad NW, JB Jones, and W Chun (2001) Laboratory Guide for Identification of Plant Pathogenic Bacteria. $3^{\text {rd }}$ Ed. APS Press, St. Paul, 373p.

Scortichini M (1994) Leaf spot and blight of Dieffenbachia amoena caused by Pseudomonas marginalis pv. Marginalis. Plant Pathology (43): $941-943$.

Wright PJ, Rd Cronin, and CN Hale (1992) Afield andstorage rot of onion caused by Pseudomonas marginalis. New Zealand Journal of Crop and Horticultural Science (20): 435-438. 